\title{
Assessment of Trace Element Daily Intake Based on Consumption Rate of Foodstuffs in Bandung City
}

\author{
E. Damastuti ${ }^{\star}$ W.Y.N. Syahfitri, M. Santoso and D.D. Lestiani \\ Nuclear Technology Center for Materials and Radiometry, National Nuclear Energy Agency \\ Jl. Tamansari 71, Bandung 40132, Indonesia
}

\section{ARTICLE INFO}

Article history:

Received 5 December 2011

Received in revised form 7 April 2012

Accepted 16 April 2012

Keywords:

Foodstuffs

Trace element

NAA

Daily intake

\begin{abstract}
A B S T R A C T
Trace elements are required by human body and have a variety role in biochemical functions mostly as catalyst for enzymatic activity in human body. Some trace elements are essential since they are inadequately or not synthesized by human body. The deficiency or excess of those essential trace element may cause disease and be deleterious to health. Since food is the primary source of essential elements for humans and it is an important source of exposure to toxic elements either, the levels of trace elements in consumed food products must be determined. The determination of trace elements content in foodstuffs widely consumed in Bandung city were conducted to assess their daily intake and contribution to the recommended dietary allowance (RDA) values. Food samples were collected from traditional markets spread across five regions of the Bandung city and analyzed using neutron activation analysis (NAA). Quality control of data analysis was assessed using SRM NIST 1567a Wheat Flour and 1568a Rice Flour and gave good results with \% recovery, $93.2-104.8 \%$; and $\% \mathrm{CV}, 3.8-11.6 \%$. A large variability of essential trace elements concentration in all types of foods analyzed were observed. The daily intake of $\mathrm{Cr}, \mathrm{Co}, \mathrm{Mn}, \mathrm{Se}$ and $\mathrm{Zn}$ were supplied enough by the diet, except for $\mathrm{Fe}$ which found that almost all the foods analyzed were not give a satisfying contribution to the RDA value of Fe. These result were expected could provide information of nutritional status of the society and can be a reference for government and related institution to effectively making policies and solution for public health improvement.
\end{abstract}

(C) 2012 Atom Indonesia. All rights reserved

\section{INTRODUCTION}

Trace element is an element required by human body in amounts smaller than $0.01 \%$ of the mass of the organism [1]. Trace elements have an important role in human biology as they have a variety of biochemical functions, mostly as catalyst for enzymatic activity in human bodies [1-5]. Some trace elements, such as iron, zinc, manganese, chrome, cobalt and selenium, are essential since they are either inadequately synthesized or not synthesized in the body $[2,4,6]$. However, those essential trace elements become toxic when their concentration become excessive. The high concentrations, as also depletion in the concentration of those essential trace elements, may cause various metabolic instabilities due to enzyme dysfunction $[3,7,8]$. Each elements has its own function and described in Table 1 . The adverse

\footnotetext{
* Corresponding author.
}

E-mail address: endah_dt@batan.go.id effect of deficiencies and also toxicities of each elements were also listed in Table 1.

Table 1. Function, adverse effects of deficiency and excessive consumption of elements [9-15]

\begin{tabular}{|c|c|c|c|}
\hline Element & Function & $\begin{array}{c}\text { Adverse effect of } \\
\text { deficiency }\end{array}$ & $\begin{array}{c}\text { Adverse effect of } \\
\text { excessive consumption }\end{array}$ \\
\hline Co & $\begin{array}{l}\text { As a part of vitamin } \\
\mathrm{B}_{12} \text {, stimulates the } \\
\text { production of red } \\
\text { blood cells. }\end{array}$ & $\begin{array}{l}\text { A deficiency in cobalt is } \\
\text { ultimately a deficiency } \\
\text { in vitamin B } 12 \text {. }\end{array}$ & $\begin{array}{l}\text { Lung effects, such as } \\
\text { asthma and pneumonia, } \\
\text { vomiting and nausea, } \\
\text { vision problems, heart } \\
\text { problems, thyroid } \\
\text { damage }\end{array}$ \\
\hline $\mathrm{Cr}$ & $\begin{array}{l}\text { Helps to maintain } \\
\text { normal blood } \\
\text { glucose levels }\end{array}$ & $\begin{array}{l}\text { Impaired glucose } \\
\text { tolerance, neuropathy }\end{array}$ & Chronic renal failure \\
\hline $\mathrm{Fe}$ & $\begin{array}{l}\text { Component of } \\
\text { hemoglobin and } \\
\text { numerous enzymes, } \\
\text { prevent microcytic } \\
\text { hypochromic anemia }\end{array}$ & $\begin{array}{l}\text { Anemia, impaired } \\
\text { cognitive development, } \\
\text { impaired learning ability }\end{array}$ & Gastrointestinal distress \\
\hline $\mathrm{Mn}$ & $\begin{array}{l}\text { Involved in the } \\
\text { formation of bone as } \\
\text { well as in enzymes } \\
\text { involved in amino } \\
\text { acid, cholesterol, and } \\
\text { carbohydrate } \\
\text { metabolism }\end{array}$ & $\begin{array}{l}\text { Poor reproductive } \\
\text { performance, growth } \\
\text { retardation, abnormal } \\
\text { function of bone and } \\
\text { cartilage }\end{array}$ & $\begin{array}{l}\text { Elevated blood } \\
\text { concentration and } \\
\text { neurotoxicity }\end{array}$ \\
\hline $\mathrm{Se}$ & $\begin{array}{l}\text { Defense against } \\
\text { oxidative stress and } \\
\text { regulation of thyroid }\end{array}$ & $\begin{array}{l}\text { Develop of a form of } \\
\text { heart disease, } \\
\text { hypothyroidism, }\end{array}$ & $\begin{array}{l}\text { Hair and nail brittleness } \\
\text { and loss }\end{array}$ \\
\hline
\end{tabular}




\begin{tabular}{lll}
\hline & $\begin{array}{l}\text { hormone action and } \\
\text { the reduction and } \\
\text { oxidation status of } \\
\text { vitamin C and other } \\
\text { molecules }\end{array}$ & $\begin{array}{l}\text { weakened immune } \\
\text { system and can make } \\
\text { the body more } \\
\text { susceptible to ilnesses, } \\
\text { Keshan disease. }\end{array}$ \\
\hline $\mathrm{Zn} \quad \begin{array}{l}\text { Component of } \\
\text { multiple enzymes } \\
\text { and proteins, } \\
\text { involved in the } \\
\text { regulation of gene } \\
\text { expression }\end{array}$ & $\begin{array}{l}\text { Growth retardation, loss } \\
\text { of appetite, impaired } \\
\text { immune function, hair }\end{array}$ & $\begin{array}{l}\text { loss, diarrhea, } \\
\text { impotence, } \\
\text { hypogonadism and } \\
\text { mental lethargy }\end{array}$ \\
\hline
\end{tabular}

The amount of elements intake by human is straightly related to their concentration in foodstuff [16], since food is the primary source of those element to enter the human body. Therefore the levels of essential and toxic elements in consumed food products need to be determined. In developed countries, despite the large food supply, special attention to the intake levels of some of these nutrients is required [17]. In Indonesia, the chronic diseases such as anaemia and osteoporosis, due to inadequate dietary intakes of $\mathrm{Fe}$, has been observed until recent day but limited in particular segments of a population [18-20], and even the data of essential elements in foodstuffs in Indonesia listed in Indonesian food composition tables (PERSAGI, 2009) are limited, especially for the essential trace element mentioned before [21]. Therefore, to evaluate the intake levels of elements in the total diet is relevance for assessing the adequacy of the diet with respect to these nutritional elements and for evaluating a possible risk due to low and high consumption. Studies of essential trace elements in food and diets are also fundamental to the reduction of malnutrition, improvement of human welfare and resistance to disease.

The objective of this research is to determine the essential trace elements in several foods that most frequently consumed in Bandung city for assessing the adequacy intake of $\mathrm{Cr}, \mathrm{Co}, \mathrm{Fe} \mathrm{Mn}, \mathrm{Se}$ and $\mathrm{Zn}$ of the diet. Those trace elements in foods are determined by neutron activation analysis (NAA). The results from these studies will provide information that can verify the nature of the nutrition problem within a society and the effectiveness of the specific solution or intervention as it can be used as the science-based reference for related institutions.

\section{METHODOLOGY}

\section{Sampling and sample preparation}

Food samples were collected from traditional markets in five Bandung regions (north, east, south, middle, and west). The types of collected foodstuffs were several foods that most frequently consumed in Bandung city citizen that is rice, roots (carrots), leafy vegetables (kale), fruits (bananas), fish (goldfish), tofu, tempe, chickens, and eggs. Samples collected from traditional markets represent the regions covering the North Bandung (Balubur, Sederhana, and Gerlong market), South Bandung (Caringin, M. Toha, Gordon, and Ciwastra market), East Bandung (Suci, Kircon, Ujung Berung, and Gede Bage market), West Bandung (Cimindi, Cijerah, and Ciroyom market), and Middle Bandung (Gempol, Ancol, Basalamah, Baru market, and Pamoyanan market). Figure 1 shows the sampling location map. Each type of food was weighed individually (only edible portion), and then mashed together using titanium blade-blender. Food sample that has been smooth and homogeneous were weighed and placed into small tubes and the tubes were frozen in a freeze dryer at temperature of $-55^{\circ} \mathrm{C}$ under vacuum. Drying process was taken for $48 \mathrm{~h}$ until the samples were dry and had constant weight. Dried samples then refined into fine powder using a teflon mortar and pestle, then placed into polyethylene container.

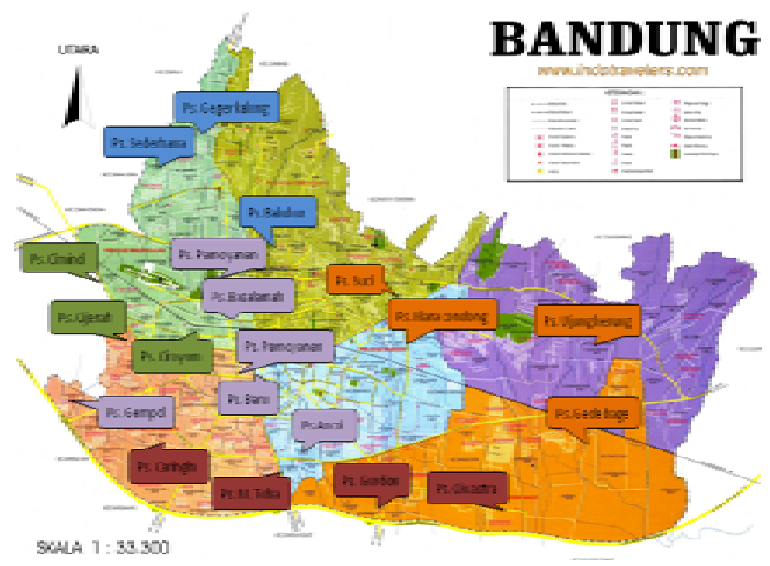

Fig. 1. Sampling Location Map.

\section{Analysis using neutron activation analysis}

As much as $0.025 \mathrm{~g}$ dried samples powder were placed into $0.274 \mathrm{~mL}$ polyethylene vial respectively and each vial then sealed by heating. Then samples were irradiated along with Standard Reference Material (SRM) NIST 1567a Wheat Flour and 1568a Rice Flour and mix standard, consist of $0.1 \mu \mathrm{g}$ of Se; $0,2 \mu \mathrm{g} \mathrm{Cr} ; 0,2 \mu \mathrm{g} \mathrm{Co} ; 10 \mu \mathrm{g}$ $\mathrm{Zn}$ and $20 \mu \mathrm{g}$ of $\mathrm{Fe}$, for 2 hours at thermal neutron flux of $10^{13} \mathrm{n} . \mathrm{cm}^{-2} . \mathrm{s}^{-1}$ in rabbit system facilites of multipurpose reactor the G.A. Siwabessy, Serpong. Samples were let to decay for a month then measured for $55000 \mathrm{~s}$ using a gamma spectrometer with high resolution of HPGe detector. 
The spectrum was observed using Genie 2000 software. For short half-life elements, a $0.025 \mathrm{~g}$ samples were irradiated along with Standard Reference Material NIST 1568a Rice Fluor and standard of $0,2 \mu \mathrm{g} \mathrm{Mn}$, for 2 minutes at at thermal neutron flux of $10^{13} \mathrm{n} \cdot \mathrm{cm}^{-2} \cdot \mathrm{s}^{-1}$ in rabbit system facilites of multipurpose reactor the G.A. Siwabessy, Serpong, then samples were measured for $200 \mathrm{~s}$ using a gamma spectrometer with high resolution of HPGe detector.

\section{Quality control and data analysis}

The SRM was used as quality control assesment of data validity. The results of SRM analysis were compared with its certificate value and evaluated its accuracy and precission by $\%$ recovery and \% CV calculation. Net areas from Genie 2000 were used to calculate the concentrations of elements in the samples using a comparative method.

\section{RESULT AND DISCUSSION}

To asses the reliability of the result obtained and the accuracy of analytical methods used in this activity, the SRM, which has similar matrix with samples, was also analyzed in the same conditions as the samples. The results of SRM NIST 1567a Wheat Flour and 1568a Rice Flour are listed in Table 2. It is shows that the result obtained are in good agreement with certified values. Analytical accuracy, described as \% recovery, are in the range $93.2-104.8 \%$; while analytical precision, described as \% CV are in the range $3.8-11.6 \%$. Both analytical accuracy and precision were acceptable according to AOAC International guidelines [22].

Tabel 2. Quality control assesment using SRM NIST 1567a Wheat Flour and 1568a Rice Flour

\begin{tabular}{|c|c|c|c|c|c|c|}
\hline No. & Element & SRM & $\begin{array}{c}\text { Certified } \\
\text { Value } \\
(\mathrm{mg} / \mathrm{Kg})\end{array}$ & $\begin{array}{c}\text { Result } \\
(\mathrm{mg} / \mathrm{Kg})\end{array}$ & $\% \mathrm{CV}$ & $\%$ rec \\
\hline 1 & $\mathrm{Mn}$ & RF $1568 \mathrm{a}$ & $20 \pm 1.6$ & $19.9 \pm 0.8$ & 3.8 & 99.4 \\
\hline 2 & Co & RF 1568a & 0.018 & $0.018 \pm 0.001$ & 4.6 & 102.4 \\
\hline 3 & $\mathrm{Fe}$ & WF $1567 a$ & $14.1 \pm 0.5$ & $13.2 \pm 1.4$ & 11.6 & 93.2 \\
\hline 4 & $\mathrm{Se}$ & RF 1568a & $0.38 \pm 0.04$ & $0.36 \pm 0.03$ & 8.6 & 94.2 \\
\hline \multirow{2}{*}{5} & \multirow{2}{*}{$\mathrm{Zn}$} & WF $1567 a$ & $11.6 \pm 0.4$ & $11.4 \pm 0.9$ & 8.3 & 98.6 \\
\hline & & RF 1568a & $19.4 \pm 0.5$ & $20.3 \pm 1.3$ & 6.6 & 104.8 \\
\hline
\end{tabular}

The results obtained for the mean and range concentration of trace elements in foodstuffs are presented in Tabel 3. It is showed that $\mathrm{Mn}$ in fruits and bean products (tofu and tempe) has higher concentration than it found in animal products.
It has similar results to those reported in literature $[16,23]$. Tempe also has higher concentration of $\mathrm{Fe}$ and $\mathrm{Zn}$ compared to that of other foodstuffs. Meanwhile, selenium is in the very low concentration in vegetable and fruit products below the limit detection of NAA. Miguel et al, 2008, stated that the concentration of $\mathrm{Se}$ in fruits and vegetables is commonly low because fruits and vegetables has low content of protein [24]. Pappa et al, 2006, also found that selenium contents in fruits and vegetables were less than $5 \mu \mathrm{g} / \mathrm{Kg}$ [25]. For all types of foods, a relatively large variability in essential trace element concentration values was observed.

Tabel 3. Trace element range concentrations $(\mathrm{mg} / \mathrm{Kg})$ in some foodstuffs

consumed in Bandung city

\begin{tabular}{lcccccc}
\hline Foodstuffs & $\mathrm{Mn}$ & $\mathrm{Cr}$ & $\mathrm{Co}$ & $\mathrm{Fe}$ & $\mathrm{Se}$ & $\mathrm{Zn}$ \\
\hline Rice & $7.5-11.2$ & $0.004-0.180$ & $0.012-0.254$ & $0.08-9.18$ & $0.06-0.29$ & $11.9-160$ \\
\hline Carrots & $0.9-2.9$ & 0.09 & $0.001-0.002$ & $\mathrm{ND}$ & $\mathrm{ND}$ & $1.2-4.8$ \\
\hline Kale & $0.42-7.5$ & 0.06 & $0.015-0.083$ & $14.3-38.9$ & $\mathrm{ND}$ & $32.9-44.0$ \\
\hline Banana & $11.9-44.1$ & $0.05-0.20$ & $0.002-0.009$ & $5.33-5.34$ & $\mathrm{ND}$ & $2.3-5.8$ \\
\hline White Tofu & $5.2-11.9$ & 0.04 & $0.05-0.08$ & $5.29-7.41$ & $0.04-0.17$ & $11.2-12.4$ \\
\hline Yellow Tofu & $5.8-9.1$ & $0.02-0.10$ & $0.001-0.002$ & $8.8-14.8$ & $0.02-0.06$ & $4.9-5.7$ \\
\hline Tempe & $5.7-14.3$ & $\mathrm{ND}$ & $0.005-0.008$ & $2.3-8.9$ & $0.18-0.27$ & $54.2-65.6$ \\
\hline Chicken & $\mathrm{ND}$ & $0.09-0.12$ & $0.003-0.007$ & $3.1-6.7$ & $0.11-0.22$ & $8.2-12.9$ \\
\hline Egg & 2.3 & $0.09-0.10$ & $0.004-0.014$ & $9.40-18.2$ & $0.17-0.23$ & $9.34-61.8$ \\
\hline Fish & $0.42-0.89$ & $0.17-0.25$ & $0.004-0.021$ & 2.8 & $0.16-0.27$ & $12.6-255$ \\
\hline ND: Not detected & & & & &
\end{tabular}

In assessing the daily intake, the mean concentration of each element in each food category was multiplied by consumption rate for Indonesian people. The consumption rate of Indonesian were shown in Tabel 4. The results of estimated daily intake of trace elements obtained from the calculation is then compared to that of Recommended Dietary Allowance Value (RDA). RDA is the average daily intake level that is sufficient to meet the nutrient requirements of nearly all (97-98\%) healthy individuals in a particular life stage and gender group and it is commonly use as a standard value in assessing the adequacy of daily intake [9]. The results of estimated daily intake of trace elements and distribution of each foodstuffs to Recommended Dietary Allowance value are presented in Fig. 2. It can be seen in Fig. 2, that the main contribution to fulfill RDA value were came from rice. Rice were the stapple food that widely consumed in Indonesia. The food habits of Indonesia people, not least in Bandung city, mostly consist of carbohydrate and it explains the large contribution of rice to the trace element daily intake 
for inhabitant in Bandung city. Figure 2.a shows that the daily intakes of $\mathrm{Cr}$ in rice were slightly exceeded its RDA value, but it is still in the safety range recommended by The Committee on Dietary Allowance, Food and Nutrition of National Research, 0.05 to $0.2 \mathrm{mg} /$ day [26].

The cobalt intake from rice were also exceeded its RDA value as shown at Fig. 2.b, but there is no data of tolerable upper intake level (UL) of cobalt. The UL is the highest level of daily nutrien intake that do not pose a risk of adverse health effects to almost all individuals in the general population [12]. However, the cobalt intake from rice were still safe for health since it belows the threshold value of cobalt consumption in foods, $1.94 \mathrm{mg} / \mathrm{kg}$ [21]. Beside rice, the high contribution of $\mathrm{Mn}$ intake is also from kale (Fig. 2.c). Kale is a leafy vegetables easily found and widely consumed in Bandung and other regions in Java island. Tempe as one of soybean products that popular in Indonesia also gives high contribution of $\mathrm{Mn}$ intake.

Similar to the previous elements, $\mathrm{Fe}, \mathrm{Se}$ and $\mathrm{Zn}$ intake are highly contributed by rice as can be seen in Fig. 2 d, e and f. Daily intake of Fe in Fig. 2.d shows that 10 food commodities were below RDA values. RDA values for the Fe element is recommended for adult males of $8 \mathrm{mg} / \mathrm{day}$ and females mature at about $18 \mathrm{mg} /$ day. FAO (Food and Agriculture Organization) or WHO (World Health Organization) recommends that the amount of iron that must be consumed should be based on the amount of iron loss in the body [30]. Therefore the RDA value of $\mathrm{Fe}$ for men and women, according to their need, are different. Of the various types of food, kale contributes the highest $\mathrm{Fe}$, about 11.58 to $43.8 \%$ to RDA for adult men and approximately 5.15 to $19.47 \%$ meet RDA for adult women. Iron derived from animal food sources is more easily absorbed by the body which is about $30 \%$, compared to that derived from vegetable sources of food that is around $10-20 \%$, due to the high levels of phytic acid, known as inositol hexakisphosphate (IP6), in plant-based foods that can inhibit absorption of Fe in the body [30]. Figure $2 \mathrm{e}$ shows that rice meets the highest Se intake compared to that of food types. The Se content in rice is lower in comparison to other types of food such as eggs, fish, tempe, and chicken, but the rice contributing the largest intake of Se. This is related to the consumption patterns of Indonesian society that is more dominated by rice as a staple food and source of carbohydrate as compared with the side dishes, vegetables and fruit. Tempe, kale and rice are the highest contributors to $\mathrm{Zn}$ intake as shown in Fig. 2.f i.e. $11 \%, 23$ and $21 \%$, respectively. The results of the determination of daily trace elements intake from various foodstuff in Bandung city, Indonesia, shows that the pattern of public consumption is largely focused on the sources of carbohydrates such as rice.

These results show that the trace element contents in several foodstuffs widely consumed in Bandung city were varied. Some food types contain high contents in one element and low in the other. In order to meet the RDA value of trace elements and to obtain a balanced diet, a variety of foodstuffs should be consumed appropriately.

Tabel 4. Consumption rate of foodstuffs

\begin{tabular}{|c|c|c|c|}
\hline \multirow{2}{*}{ No. } & \multirow{2}{*}{ Foodstuffs } & Consumption rate & \multirow{2}{*}{ Ref. } \\
\hline & & (Kg/day) & \\
\hline 1 & Rice & 0.223 & 23 \\
\hline 2 & Carrot & 0.004 & 23 \\
\hline 3 & Kale & 0.090 & 23 \\
\hline 4 & Banana & 0.005 & 27 \\
\hline 5 & White Tofu & 0.022 & 28 \\
\hline 6 & Yellow Tofu & 0.022 & 28 \\
\hline 7 & Tempe & 0.022 & 28 \\
\hline 8 & Chicken & 0.020 & 23 \\
\hline 9 & Egg & 0.019 & 27 \\
\hline 10 & Fish & 0.002 & 27 \\
\hline
\end{tabular}

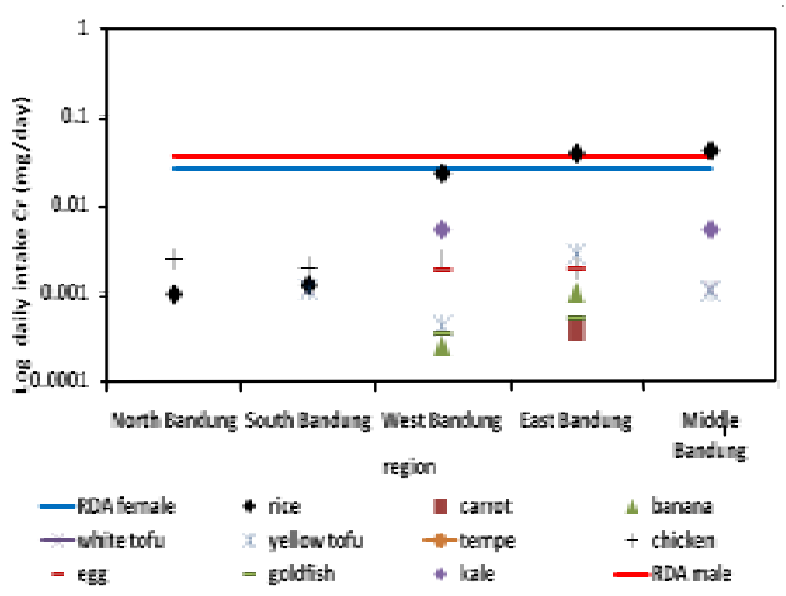

(a). $\mathrm{Cr}$

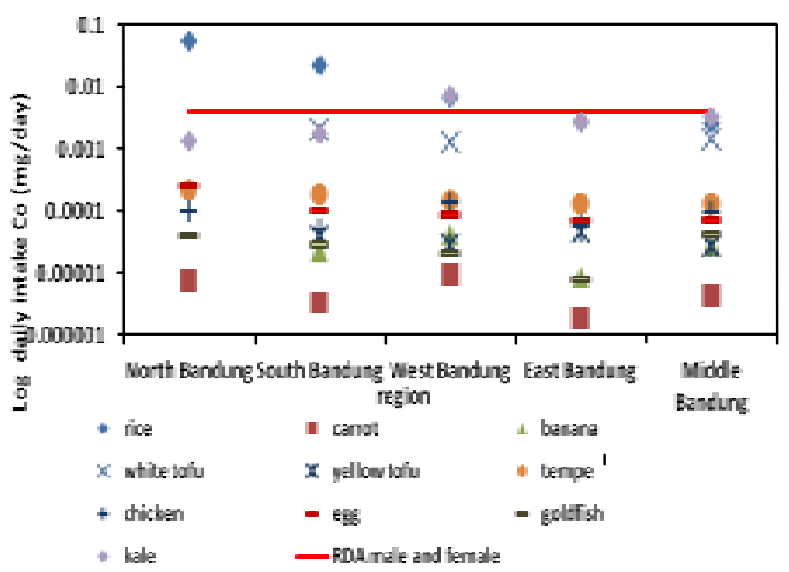

(b). Co 


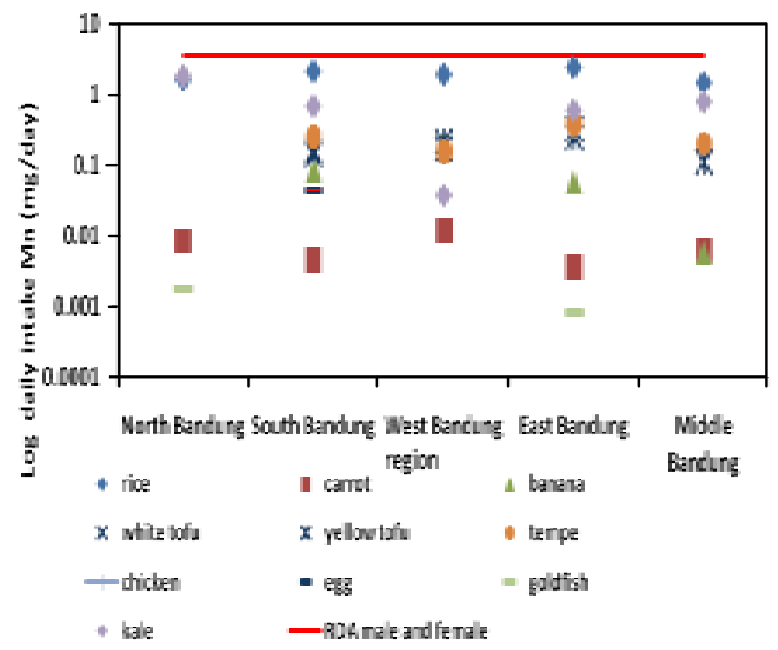

(c). $\mathrm{Mn}$

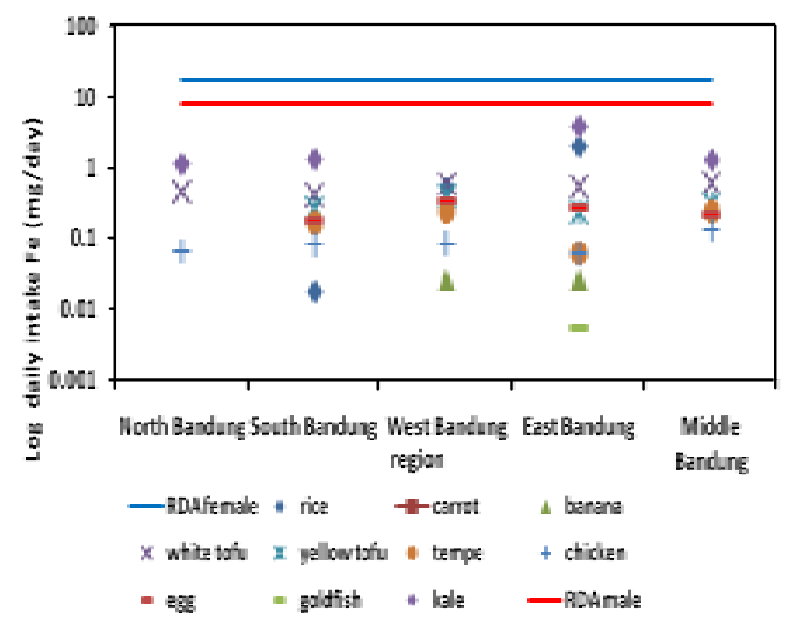

(d). $\mathrm{Fe}$

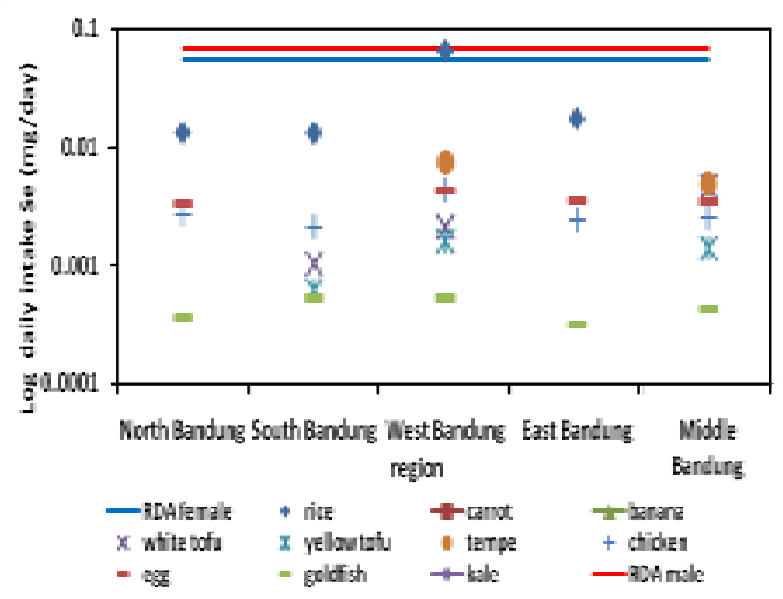

(e). Se

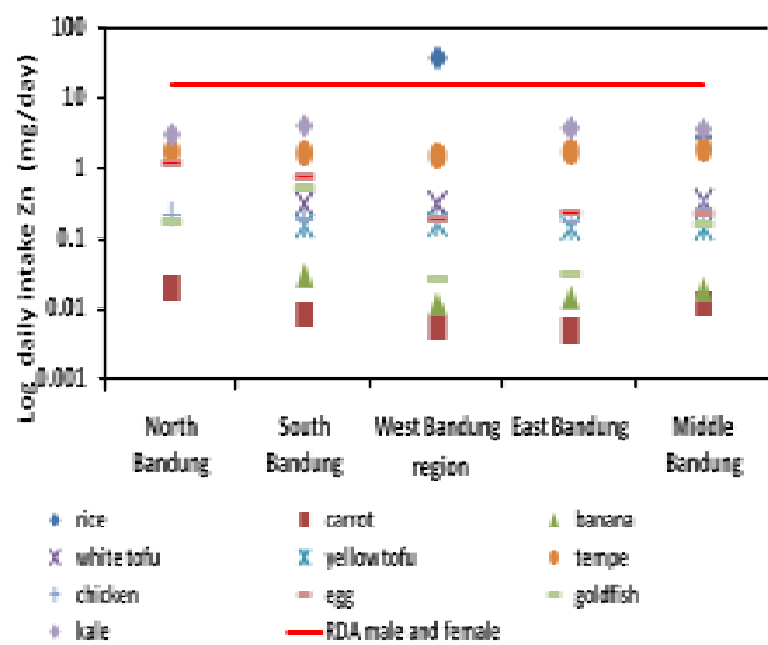

(f). $\mathrm{Zn}$

Fig. 2. Daily intake of (a) $\mathrm{Cr}$, (b) $\mathrm{Co}$, (c) $\mathrm{Mn}$, (d) $\mathrm{Fe}$, (e) Se and (f) $\mathrm{Zn}$ and each foodstuff contributions to RDA value [29].

\section{CONCLUSION}

The reliability of the result obtained and the accuracy of analitycal methods show a good performance with \% recovery, $93.2 \sim 104.8 \%$; and $\%$ $\mathrm{CV}, 3.8 \sim 11.6 \%$. A large variability of essential trace elements concentration in all types of foods analyzed were observed. Manganese in fruits and bean products has higher concentration than it found in animal products. Selenium were also in the very low concentration in vegetable and fruit products. The daily intake of mostly element reported, are conveniently supplied by the diet, except for Fe where almost all types of foods observed give low contribution to the RDA value. However, that the main contributor of trace element intake is rice, it is needed to be considered that a healthy diet is not just to fulfill the nutrition requirements but also should consist of balanced-varied diet. Further research is needed by evaluating the use of spices and the elemental loss during cooking period to give more accurate information about the status of nutrition intake consumed by inhabitants in Indonesia.

\section{ACKNOWLEDGEMENTS}

The authors would like to extends their thank to Natalia Adventini, Syukria Kurniawati, Indah Kusmartini and Djoko Prakoso, also to others for their valuable contribution. 


\section{REFERENCES}

1. A.N. Rao, Editorial, Online J. Health Allied Scs. 4 (2005) 1. http://cogprints.ecs.soton.ac. uk/view/subjects/OJHAS.html. Retrieved in August (2010).

2. S. Saraglocu, K.O. Saygi, O.D. Uluozlu, M. Tuzen and M. Soylak, Food Chem. 105 (2007) 280.

3. V. Singh and A.N. Garg, Food Chem. 94 (2006) 81.

4. A. Lesniewicz, K. Jaworska and W. Zyrnicki, Food Chem. 99 (2005) 670.

5. P. Smrkolj, L. Pograjc, C.H. Ribi and V. Stibilj, Food Chem. 90 (2005) 691.

6. E.P. Nardi, F.S. Evangelista, L. Tormen, T.D. Saint'Pierre, A.J. Curtius, S.S. de Souza, and F. Barbosa Jr., Food Chem. 112 (2009) 727.

7. M. Tuzen and M. Soylak, Food Chem. 102 (2007) 1089.

8. A. Kumar, A.G.C. Nair, A.V.R. Reddy and A.N. Garg, Food Chem. 89 (2005) 441.

9. Anonymous, Food and Nutrition Board, Institute of Medicine, National Academies, USA, Dietary Reference Intake, in: Recommended Intakes for Individual, Elements (2004).

10. Anonymous, Food and Nutrition Board, Institute of Medicine, National Academies, USA, Dietary Reference Intake, in: Recommended Intakes for Individual, Electrolytes and Water (2004).

11. Anonymous, Dietary Supplement Fact Sheet: Chromium. http://ods.od.nih.gov. Retrieved in August (2010).

12. S.B. Goldhaber, Trace Element Risk Assessment, in: Essentiality vs.Toxicity, Regulatory Toxicology and Pharmacology (2003) 232.

13. Anonymous, Dietary Supplement Fact Sheet: Zinc. http://ods.od.nih.gov. Retrieved in August (2010).

14. Anonymous, Dietary Supplement Fact Sheet: Selenium. http://ods.od.nih.gov. Retrieved in August (2010).
15. P.C. Onianwa, A.O. Adeyemo, O.E. Idowu and E.E. Ogabiela, Food Chem. 72 (2001) 89.

16. E.E. Santos, D.C. Lauria and C.L. Porto da Silveira, Sci. Total Environ. 327 (2004) 69.

17. B.G. Lombradi, A. Agucci, M. Cappelloni and G. Di Lullo, Br. J. Nutr. 90 (2003) 1117.

18. S. Patimah, J. Sains dan Teknologi 7 (2007) 137.

19. A.E. Puji, S. Satriani, N. Nadimin and F. Fadliyah, The relationship of maternal knowledge and their consumption patterns in the incidence of nutritional anemia in pregnant women at Kassi-Kassi health centers, Nutrition Food Media 10 (2010) 50. (in Indonesian).

20. A. Wijanarko, A. Mursyid and T. Siswati, J. Tech. Health 8 (2012) 56. (in Indonesian).

21. M. Mie, H. Hermana and N.A. Zulfianto, Indonesian Food Composition Tables, Nutritionist Indonesia, Jakarta (2009). (in Indonesian).

22. Anonymous, AOAC International, Guidelines for Single Laboratory Validation (2002).

23. H. Alex, et al., Environ. Geochem. Health. 27 (2005) 475.

24. N.A. Miguel, C.V. Carmen, Sci. Total Environ. 400 (2008) 115.

25. Pappa, et al., Sci. Total Environ. 372 (2006) 100.

26. P.P. Sirichakwal, P. Praprasri, P. Jarupun and K. Ratchanee, J. Food Compo. Anal. 18 (2008) 47.

27. Anonymous, National Statistic Agency, Food Consumption Rate (2009). (in Indonesian).

28. E. Ginting, S.S. Antarlina and S. Widowati, J. Litbang Pertanian 28 (2009) 79. (in Indonesian).

29. Anonymous, Dietary References Intakes (DRIs), in: Recommended Intakes for Individuals, Elements. Food and Nutrition Institute of Medicine, National Academies of Sciences 2004

30. F.G. Winarno, The Chemistry and Nutrient, $1^{\text {st }}$ Ed., Gramedia Pustaka Utama Co. Inc., Jakarta (1997). (in Indonesian). 